\title{
Utilización del colgajo de músculo temporal en cirugía reconstructiva maxilofacial. Revisión de 104 casos
}

\author{
Use of the temporalis muscle flap in maxillofacial reconstruction \\ surgery. A review of 104 cases
}

I. Zubillaga Rodríguez', G. Sánchez Aniceto², I. García Recuero², J.J. Montalvo Moreno

Resumen: Introducción: el colgajo de músculo temporal ha sido empleado en reconstrucción craneofacial desde hace más de 100 años. El primer caso descrito en la literatura fue publicado por Lentz en 1895. Hoy en día el uso de colgajos locales con músculo temporal parece ser desplazado por el uso de colgajos libres microvascularizados en la reconstrucción craneofacial. En nuestra experiencia dichos colgajos locales constituyen una opción segura en muchos de nuestros pacientes.

Objetivos: mostrar nuestras indicaciones y resultados en reconstrucción craneofacial con el empleo del colgajo de músculo temporal.

Material y método: análisis retrospectivo de nuestra experiencia con el colgajo de músculo temporal en la última década.

Resultados: hemos empleado un total de 108 colgajos miofasciales temporales en pacientes adultos con las siguientes indicaciones: reconstrucción de defectos postmaxilectomía (44); cirugía de base de cráneo (25) incluyendo fosa craneal anterior, media y posterior; cavidad oral y orofaringe (23); tras exenteración orbitaria en pacientes oncológicos (6); anquilosis de ATM (6); secuelas faciales postraumáticas (2); reanimación facial (2).

Conclusiones: el colgajo de músculo temporal es una de las primeras opciones en cirugía reconstructiva oncológica craneofacial, de la ATM y base de cráneo. La disección traumática del colgajo y la sutura a tensión predisponen la aparición de complicaciones como necrosis o dehiscencia de la sutura.

Palabras clave: Músculo temporal; Cirugía reconstructiva craneofacial; Maxilectomía; Base de cráneo.
Abstract: Introduction: Temporalis miofascial flap has been used for craniofacial reconstruction since more than 100 years. The first described case in the medical literature was published by Lentz in 1895. The use of pedicled temporalis muscular flaps in cranial or facial reconstruction seems to be shifted nowadays by microvascular free flaps. Nevertheless, in our experience, this miofascial pedicled flap demonstrates to be a safe option for midfacial and lateral cranial base defects.

Aims: To show our indications and results using the temporalis flap in craniofacial reconstruction.

Material and methods: A retrospective analysis of our experience with temporalis flap along the last decade.

Results: A total of 108 flaps have been used in the following situations: postmaxillectomy defect reconstruction (44); cranial base (25) including anterior, middle and posterior cranial fossas; oral cavity and oropharynx (23); orbital exenteration (6); Temporomandibular joint ankylosis (6); others (2) with an overall success rate (no partial or total flap failure) over $94 \%$.

Conclussions: Temporalis muscle flap is one of the «first choice» elections in reconstructive craniofacial surgery, for midfacial and cranial base indications. Non-careful surgical dissection and flap suture under tension predispose to complications such as flap necrosis (commonly partial) and wound dehiscence.

Key words: Temporalis muscle; Craneofacial reconstructive surgery; Maxillectomy; Cranial base surgery.

\footnotetext{
1 Médico Residente

2 Médico Adjunto

3 Jefe de Servicio

Servicio de Cirugía Oral y Maxilofacial, Hospital Universitario 12 de Octubre, Madrid
}

Correspondencia:

Ignacio Zubillaga Rodríguez

Servicio de Cirugía Oral y Maxilofacial.

Hospital Universitario 12 de Octubre.

Avenida de Córdoba s/n. 28041 Madrid

E-mail: ignaciozubillaga@yahoo.es 


\section{Introducción}

El músculo temporal ha sido empleado en cirugía reconstructiva craneofacial desde hace más de 100 años. Fue Lentz en 1895 el primero en publicar la utilización de dicho músculo en un paciente con anquilosis temporomandibular, siendo asimismo uno de los primeros colgajos musculares descritos. ${ }^{1}$ Golovine describió su uso tras la realización de una exenteración orbitaria en $1898 .{ }^{2}$ Gillies $^{3}$ en 1919 aplicó el músculo para reconstruir un defecto en la mucosa yugal y en 1930 como técnica de reanimación facial.

Campbell ${ }^{4}$ en 1948 lo aplicó como técnica reconstructiva postmaxilectomía siendo lecho receptor de injertos óseos. También ha sido utilizado para aislar el sistema nervioso central tras cirugía oncológica de base de cráneo ${ }^{5,6}$ y para cierre de fisuras palatinas no separadas en adultos.

Hoy en día el uso de colgajos locales como el músculo temporal parece ser desplazado por el uso de colgajos libres microvascularizados en reconstrucción maxilofacial pero en nuestra experiencia constituye una opción versátil y segura para nuestros pacientes.

\section{Objetivos}

1. Mostrar nuestras indicaciones y resultados en cirugía reconstructiva maxilofacial con el músculo temporal.

2. Breve descripción anatómica, variantes del colgajo y técnica quirúrgica con sus refinamientos.

3. Análisis de las complicaciones

\section{Material y método}

Análisis retrospectivo de 104 pacientes con defectos del área maxilofacial reconstruidos con 108 colgajos miofasciales de músculo temporal desde enero de 1991 hasta junio de 2003 en el servicio de Cirugía Oral y Maxilofacial del Hospital Universitario «12 de Octubre» de Madrid.

El rango de edad de los pacientes fue de 16 a 87 años siendo la edad media de 53. Respecto a la distribución por sexo 68 eran varones y 35 mujeres. El seguimiento postquirúrgico osciló entre los 4 y los 120 meses con una media de 40 meses. En 4 pacientes se utilizó el colgajo temporal de forma bilateral presentando todos ellos anquilosis bilateral de la articulación temporomandibular.

\section{Anatomía y técnica quirúrgica}

El músculo temporal se inserta en la línea temporal superior ocupando la fosa temporal. Desciende bajo el arco cigomático hasta su inserción caudal en la apófisis coronoides y borde anterior de la rama mandibular. Con forma de abanico, tiene una longitud media anteroposterior de $8 \mathrm{~cm}$. y craneocaudal de $6 \mathrm{~cm}$. El grosor aumenta al aproximarse al arco cigomático $(1,5 \mathrm{~cm}$.) siendo de $0,5 \mathrm{~cm}$. en la periferia.

Recibe su inervación a través de ramas temporales procedentes de la tercera división del nervio trigémino las cuales penetran por

\section{Introduction}

The temporalis muscle has been used in craniofacial reconstructive surgery for more than a hundred years. Lentz was the first in 1895 in publishing the use of this muscle in a patient with temporomandibular ankylosis, and it was one of the first muscular flaps described. ' Golovine described its use after carrying out an orbital exenteration in $1898 .{ }^{2}$ Gillies $^{3}$ used the muscle in 1919 for reconstructing a defect of the jugal mucosa and, in 1930 he used it for facial reanimation.

Campbell/ in 1948 used it as a post-maxillectomy reconstructive technique, it being a recipient bed for bone grafts. It has also been used to isolate the central nervous system after oncological surgery on the base of the skulls,6 and for closing cleft palates not separated in adulthood.

Today the use of local flaps such as the temporalis muscle flap seems to have been supplanted by the use of microvascular free flaps in maxillofacial reconstruction but, in our experience, it constitutes a reliable and versatile option for our patients.

\section{Objectives}

1. To discuss the indications in our view for the use of the temporalis muscle in reconstructive maxillofacial surgery and to set out our results.

2. [To give] a brief anatomical description, to explain the different flaps and the surgical technique with its refinements.

3. To analyze complications.

\section{Material and method}

A retrospective analysis was carried out of 104 patients with defects in the maxillofacial area reconstructed with 108 myofascial flaps from the temporalis muscle from January 1991 until June 2003 in the service of Oral and Maxillofacial Surgery of the University Hospital «12 de Octubre» of Madrid.

The age range of the patients was between 16 to 87 years, with a mean age of 53 . With regard to different sexes, 68 were male and 35 were female. Postoperative followup ranged between 4 and 120 months, with an average of 40 months. The temporalis muscle was used for bilateral [reconstruction] in 4 patients due to there being bilateral ankylosis of the temporomandibular joint.

\section{Anatomy and surgical technique}

The temporalis muscle inserts onto the superior temporal line occupying the temporal fossa. It passes under the 
su cara profunda en número de 3 a 4 . Es preciso tener en cuenta la atrofia por denervación que se producirá a nivel muscular cuando es utilizado en cirugía reconstructiva de base de cráneo si ha existido lesión y/o resección del nervio trigémino.

Desde el punto de vista de su vascularización, es un músculo tipo III de la clasificación de Mathes y Nahai con los siguientes pedículos vasculares. 8,9

a. Arteria temporal profunda anterior, responsable de la vascularización del $20 \%$ anterior del territorio muscular. Penetra por la cara profunda muscular $1 \mathrm{~cm}$. anterior a la apófisis coronoides.

b. Arteria temporal profunda posterior, responsable del $40 \%$ medio del territorio muscular. De mayor diámetro que el anterior, penetra 1,7 cm. posterior a la apófisis coronoides. Ambas ramas proceden de la arteria maxilar interna.

c. arteria temporal media, responsable del $40 \%$ posterior del territorio muscular. Procede de la arteria temporal superficial.

d. ramas adicionales que parten directamente de la arteria maxilar interna en el tercio inferior muscular.

En el plano coronal, la vascularización muscular se dispone principalmente en la zona medial y lateral del músculo con densidad vascular significativa-

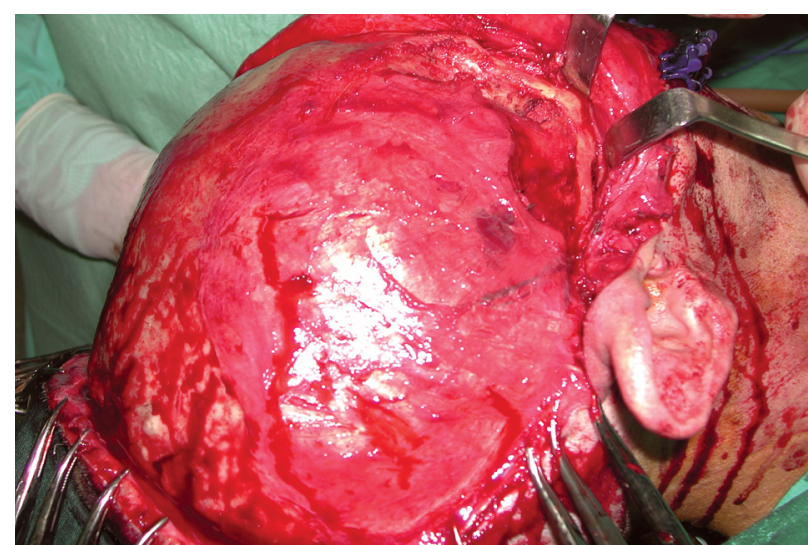

Figura 1. Abordaje coronal para tallado de músculo temporal. Figure 1. Coronal approach for harvesting of temporalis muscle.

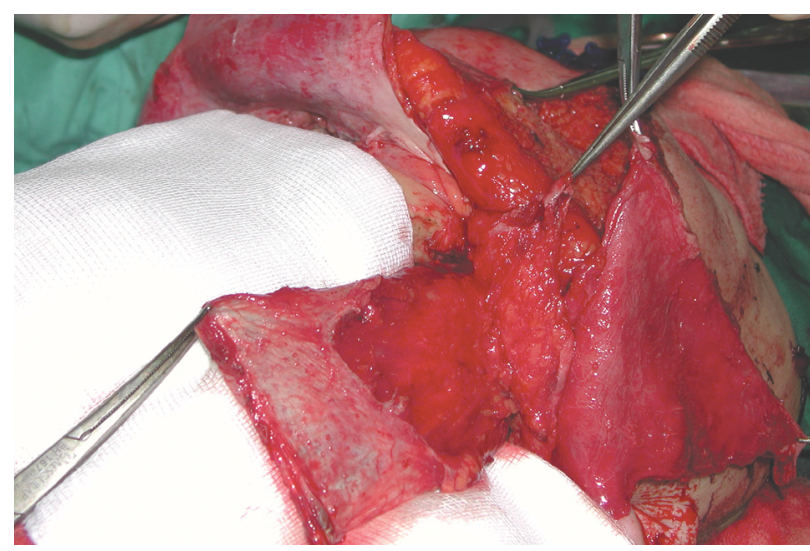

Figura 2. El abordaje coronal posibilita el tallado de colgajos regionales como fascia parietotemporal y/o galea-pericráneo.

Figure 2. Harvesting regional flaps such as the parietotemporal fascia and/or galea-pericranial flaps is possible using the coronal approach. zygomatic arch and the tapering portion attaches to the coronoid process and anterior border of the ramus of the mandible. It is fanshaped and it has an average anteroposterior length of $8 \mathrm{~cm}$. and a craniocaudal length of $6 \mathrm{~cm}$. Its thickness increases on nearing the zygomatic arch $(1.5 \mathrm{~cm})$, its peripheral area being 0.5 $\mathrm{cm}$.

It receives innervation through the temporal branches coming from the third division of the trigeminal nerve which penetrate, three to four in number, through the deep surface. It is necessary to keep in mind that denervation atrophy will be produced at a muscular level when the temporalis muscle is used in reconstructive surgery of the skull base if there has been a lesion and/or resection of the trigeminus nerve.

From the point of view of vascularization, it is a type III muscle in Mathes and Nahai's ${ }^{7}$ classification with the following vascular pedicles. 8,9

a. Anterior, deep, temporal artery responsible for $20 \%$ of the vascularization of the anterior muscle area. It penetrates the deep muscular surface $1 \mathrm{~cm}$. and is anterior to the coronoid process.

b. Posterior, deep, temporal artery, responsible for $40 \%$ of middle part of the muscle area. With a larger diameter than the former, it penetrates $1.7 \mathrm{~cm}$. and is posterior to the coronoid process. Both branches proceed from the internal maxillary artery.

c. Middle temporal artery, responsible for $40 \%$, of the posterior muscle area. It proceeds from the superficial temporal artery.

d. Additional branches that leave directly from the internal maxillary artery in the lower third of the muscle.

Muscle vascularization is situated principally in the lateral and medial areas of the muscle in the coronary plane, with a vascular density which is significantly lower than in the medial area. This distribution allows a sagittal division of the muscles which ensures vascularization and guarantees a reconstructive technique that is reliable. The vascular 2). 
Existen 5 configuraciones básicas del colgajo de músculo temporal: músculo solo, miofascial, mioperióstico, miocutáneo y mioóseo. ${ }^{11}$

En nuestra serie, todos los colgajos fueron miofascioperiósticos sobre la fosa temporal preservando así la vascularización propia del músculo temporal.

La fascia temporal es liberada de sus inserciones zigomáticas, se incrementa así el arco de rotación y especialmente en reconstrucción intraoral disminuye la posibilidad de estrangular el pedículo. En dicha reconstrucción intraoral un túnel es creado a través de la fosa infratemporal y el colgajo es vehiculizado hacia la cavidad oral con dos suturas de seda. A veces se realiza osteotomía del arco cigomático para facilitar la movilización del colgajo, reponiéndolo posteriormente mediante osteosíntesis del mismo (Fig. 3). En ocasiones es preciso aumentar el arco de rotación del colgajo para acceder sin tensión al defecto a reconstruir. Para ello es posible realizar la coronoidectomía mas frecuente en casos de reconstrucción intraoral12 (Fig. 4).

La porción de músculo temporal a tallar depende de la localización y tamaño del defecto a reconstruir, siendo posible su división coronal, sagital o el empleo completo de todo el músculo. ${ }^{8}$ Cuando el músculo va a ser utilizado parcialmente, se emplea la porción anterior para el proceso reconstructivo y la por-

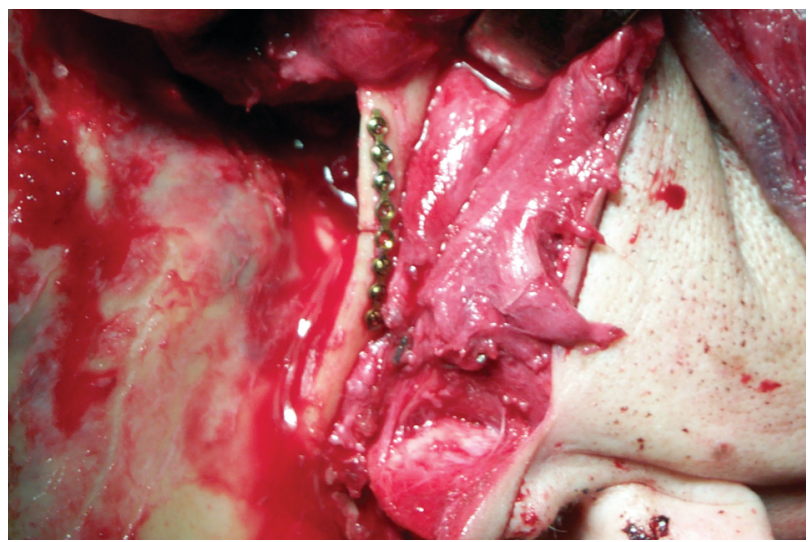

Figura 3. Osteosíntesis en arco cigomático tras vehiculización del colgajo temporal a través de la fosa infratemporal.

Figure 3. Osteosynthesis of the zygomatic arch after transposition of the temporalis muscle through the infratemporal fossa.

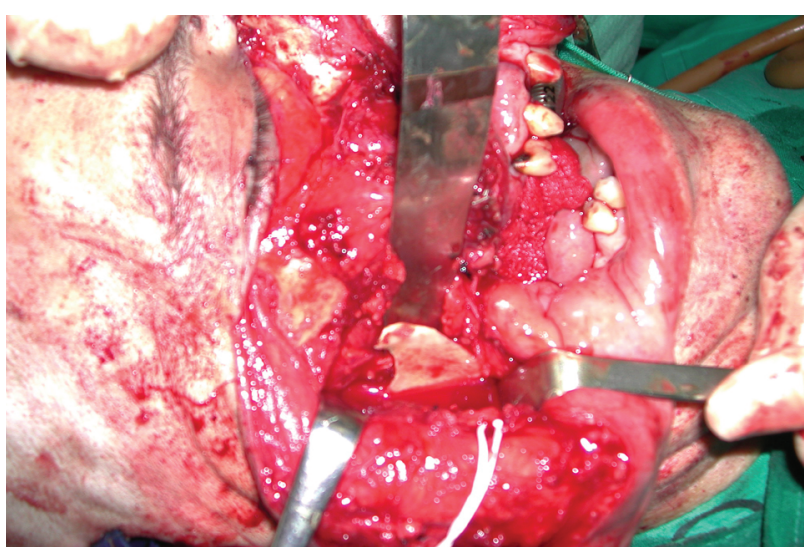

Figura 4. Exposición de apófisis coronoides previa a su osteotomía.

Figure 4. The coronoid process as seen before the osteotomy. distribution in the sagittal plane, as explained, permits therefore, a coronal division and adequate reconstruction according to the defect created. ${ }^{8}$

The venous return is produced generally through two veins that accompany each artery. Venovenous and arterioarterial intramuscular anastomosis, typical of the muscles of the periphery, is frequent. The development of anastomosis leads to local muscle edema that impedes the movement the temporalis muscle under the zygomatic arch, which is sometimes necessary for a precise reconstruction.

With regard to surgical technique, all the flaps from the temporalis muscle were harvested via a coronal approach including the necessary perfections designed to avoid damaging the frontal branch of the pair of cranial nerves VII (Fig. 1). On occasions the parietotemporal fascia is harvested if necessary during the same approach, generally to increase vascularization of the grafts used in ción posterior remanente se rota anteriormente en la fosa temporal. Se preserva una pequeña cincha muscular fija a la cresta temporal anterior que permita la sutura de dicho músculo temporal posterior remanente tras ser rotado.

\section{Indicaciones}

La proximidad anatómica del músculo temporal al tercio superior y medio facial hace que sea empleado con relativa frecuencia en el campo de la cirugía reconstructiva craneofacial.

Hemos empleado un total de 108 colgajos miofasciales temporales con las siguientes indicaciones:

A. Reconstrucción de defectos postmaxilectomía $(n=44)^{13}$ (Figs. 58).

Dependiendo del tipo de maxilectomía realizada (parcelar o ampliada) es precisa la utilización de únicamente la porción anterior del músculo temporal o del mismo en su totalidad. Dicho defecto potresección permite la vehiculización directa del músculo temporal desde su inserción en la fosa temporal bajo el arco cigo- orbital reconstruction ${ }^{10}$ (Fig. 2).

The temporalis muscle flap has five basic forms: pure muscle, myofascial, myoperiosteal, myocutaneous and myoosseous. ${ }^{11}$

In our series all flaps were myofascial-periosteal over the temporal fossa in order to preserve the temporalis muscle's own vascularization.

The temporal fascia is freed of its zygomatic parts in order to increase the arc of rotation and, with regard to intraoral reconstruction, the possibility of strangling the pedicle is in this way reduced. In this type of intraoral reconstruction a tunnel is created through the infratemporal fossa and the flap is moved towards the oral cavity with two silk sutures. Sometimes an osteotomy of the zygomatic arch is performed in order to facilitate moving the flap, and it is later replaced by means of osteosynthesis (Fig. 3). Increasing the arc of rotation of the flap is necessary on occasions, in order to reach the defect that is to be reconstructed with no tension. In order to do this a coronoidectomy can be performed which 


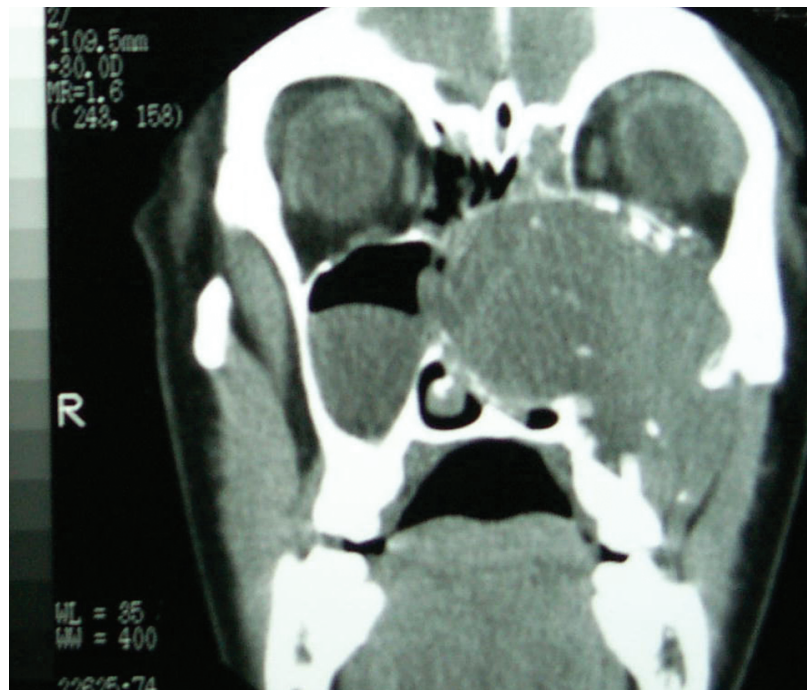

Figura 5. TAC coronal preoperatorio donde se evidencia la extensión de un fibromixoma en el tercio medio facial.

Figure 5. Preoperative coronal CT scan in which the area covered by fibromyxoma is visible in the middle third of the face.

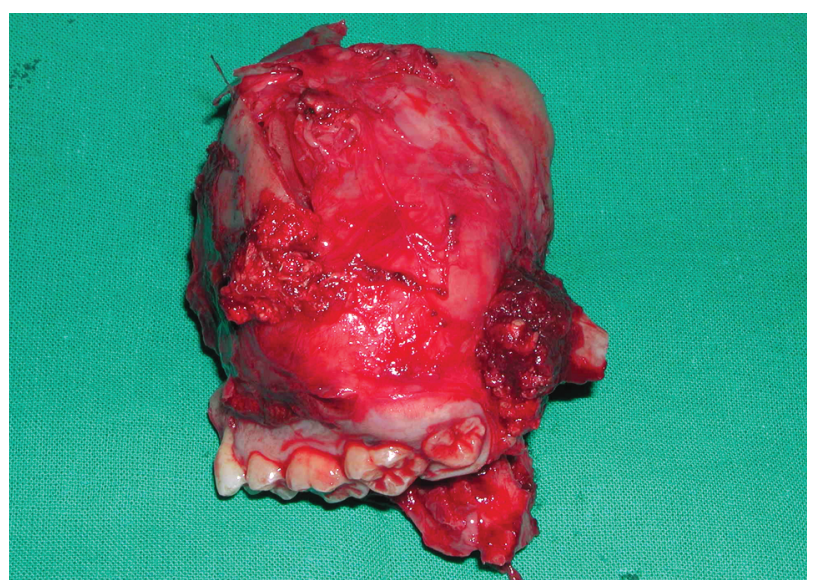

Figura 7. Especimen quirúrgico.

Figure 7. Surgical specimen.

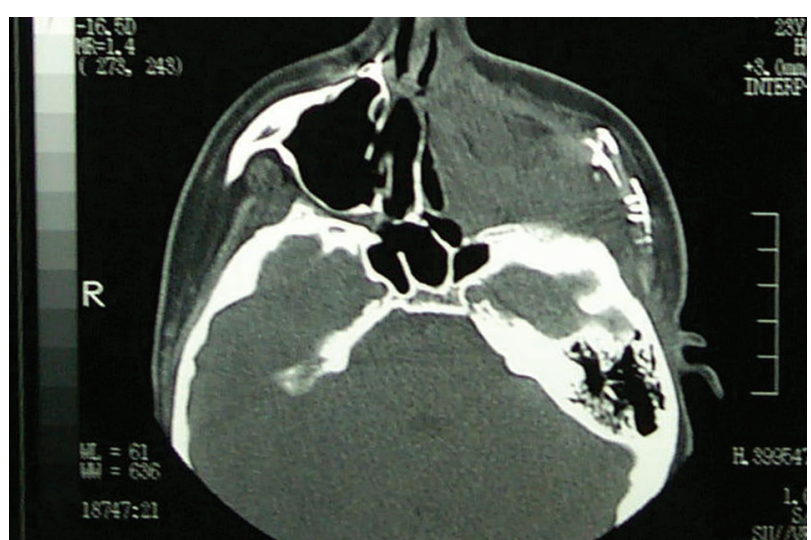

Figura 8. TAC control donde se aprecia reconstrucción del tercio medio facial con el músculo temporal.

Figure 8. CT control showing reconstruction with the temporalis muscle of the middle third of the face.

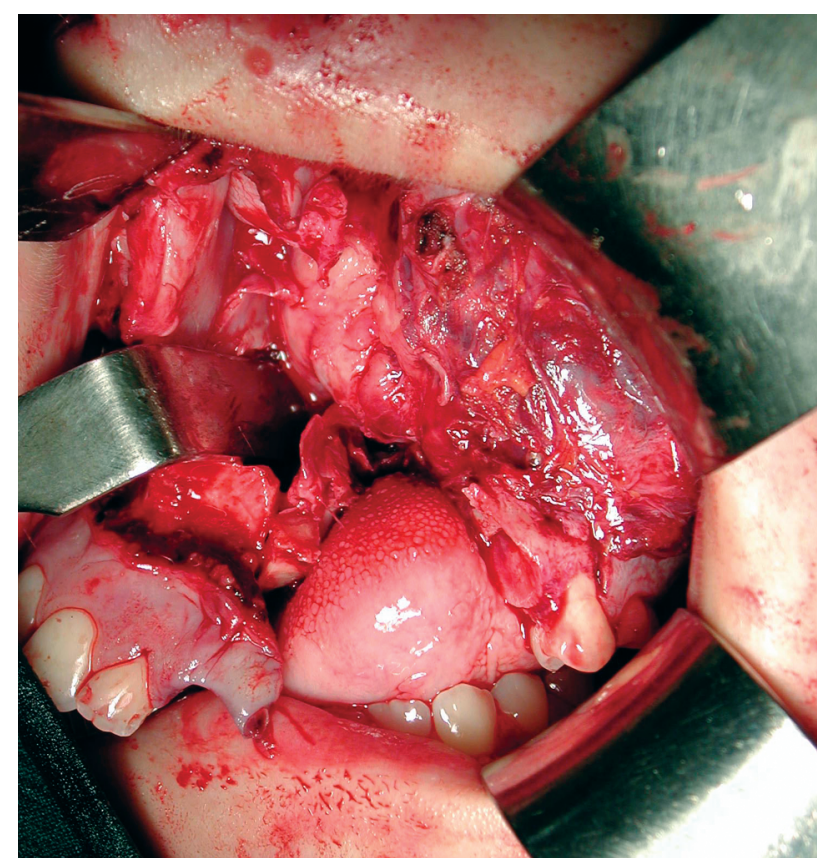

Figura 6. Abordaje transfacial que incluye degloving facial más Lefort I segmentado.

Figure 6. Transfacial approach that includes facial degloving and segmented Lefort I.

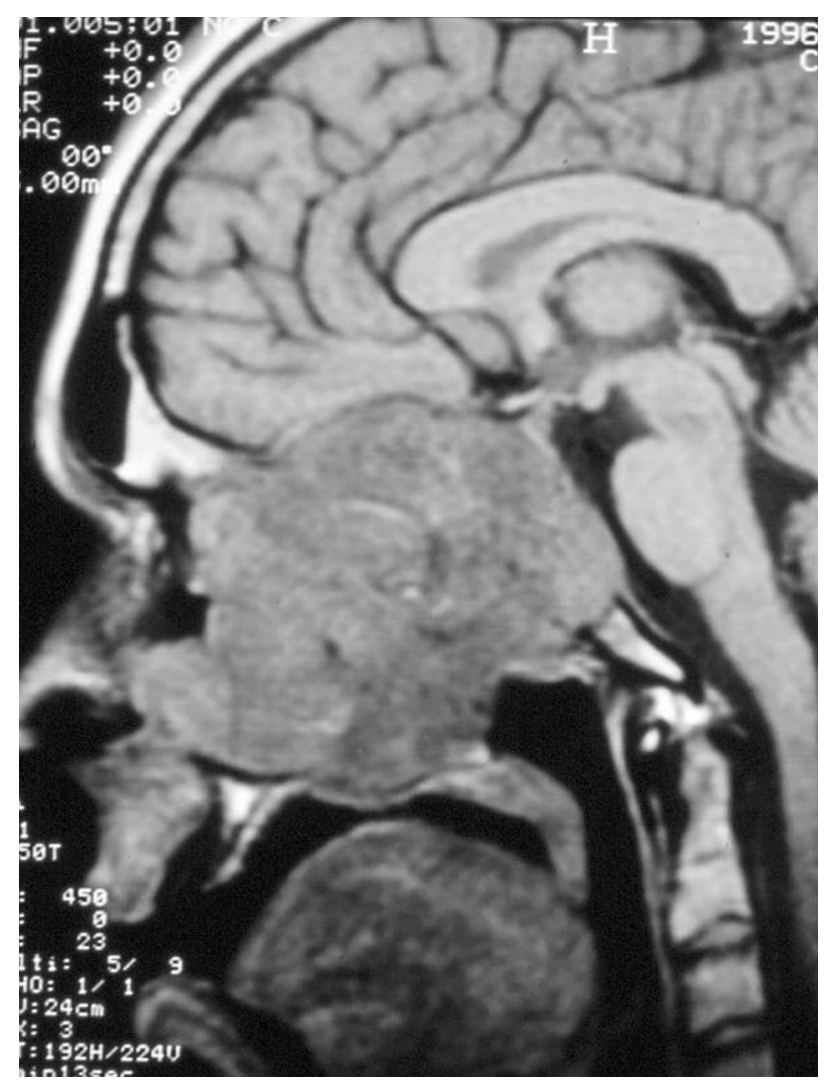

Figura 9. RNM sagital preoperatoria. Angiofibroma nasofaríngeo juvenil con extensión intracraneal.

Figure 9. Preoperative sagittal MR. Juvenile nasopharyngeal angiofibroma with intracranial extension. 
mático hacia la cavidad oral. La fascia temporal es suturada firmemente al defecto intraoral de tal forma que el músculo temporal obture el defecto. Algunos autores son partidarios del mantenimiento del arco cigomático pediculado al músculo masetero para vehiculizar la cincha de músculo temporal en aquellos pacientes que han recibido radioterapia previa local. Es posible la reconstrucción del reborde óseo alveolar uniéndolo al reborde infraorbitario y a la apófisis pterigoides con injertos de cresta iliaca a los 6 meses de la cirugía. Posteriormente se completará la rehabilitación protésica mediante la colocación de implantes osteointegrados 6 meses después. En ocasiones es precisa la realización de vestibuloplastias en este acto quirúrgico.

B. Cirugía de base de cráneo $(n=25)$ Se distribuyen los defectos postquirúrgicos en las siguientes localizaciones:

B1. Fosa craneal anterior $(n=15)$

- Resección anterolateral (n=9)

- Resección lateral $(n=6)$

B2. Fosa craneal media $(n=5)$

B3. Fosa craneal posterior $(n=2)$

B4. Clivus $(n=3)$

El objetivo fundamental perseguido es el aislamiento adecuado, evitando la presencia de espacios muertos, entre el sistema nervioso central y la vía aerodigestiva superior ${ }^{14}$ (Fig. 9-10). De esta forma será posible prevenir la aparición de fístula de líquido cefalorraquídeo con el consiguiente riesgo de meningitis asociada.

El músculo temporal aporta una cantidad sustancial de tejido bien vascularizado que asegura un sellado eficaz de la base craneal pudiendo extenderse incluso más allá de la línea media hacia el lado contralateral obliterando así posibles espacios muertos existentes. En este tipo de procedimientos quirúrgicos de la base craneal es frecuente la resección asociada de una o varias paredes orbitarias. Injertos de calora craneal son empleados para la reconstrucción de las mismas. El músculo temporal supone un aporte vascular adecuado para dichos injertos óseos libres (Figs. 11-12).

C. Cavidad oral-orofaringe $(n=23)$.

Se distribuyen los defectos a reconstruir de la siguiente manera:

- Mucosa yugal $(n=8)$.

- Paladar blando $(n=7)$.

- Trígono retromolar $(n=5)$.

- Orofaringe $(n=3)$.

La vehiculización del músculo temporal se realiza a través del túnel creado en la fosa infratemporal bajo el arco cigomático. En

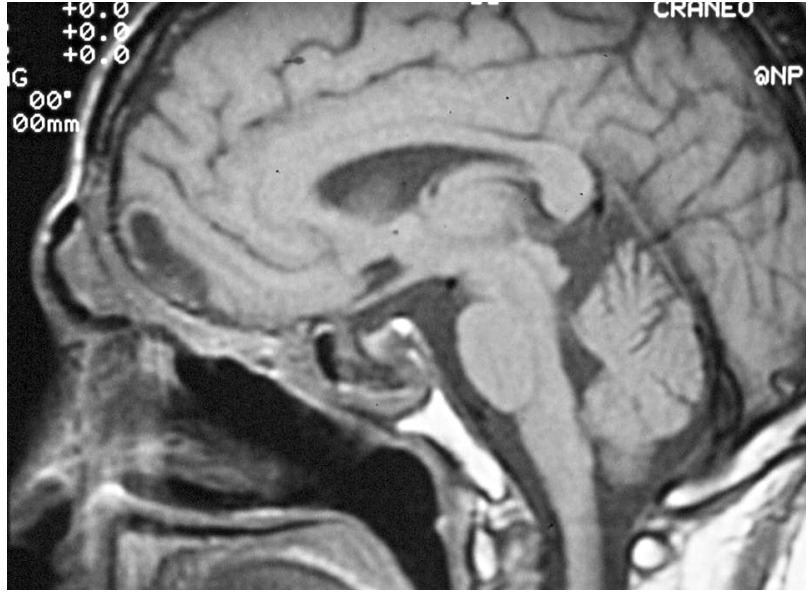

Figura 10. RNM sagital postoperatoria. Figure 10. Postoperative sagittal MR.

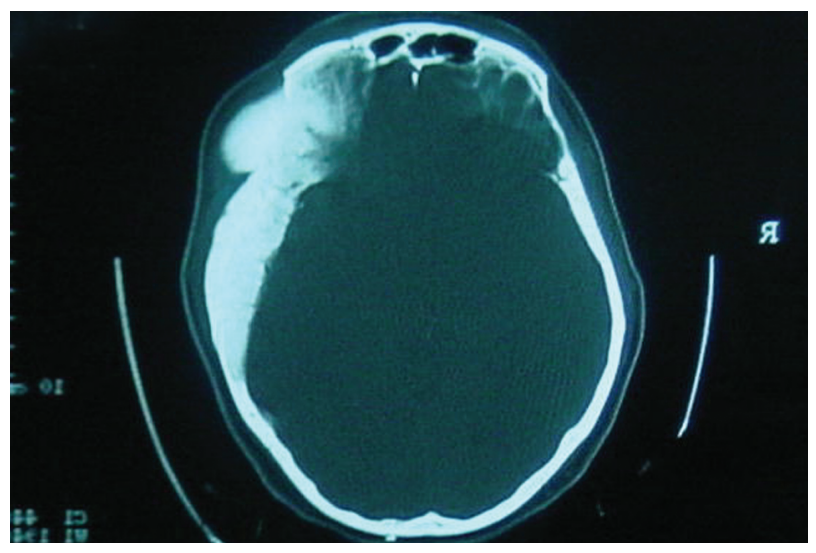

Figura 11. TAC axial. Meningioma frontotemporoesfenoidal. Figure 11. Axial CT scan frontotemporosphenoid meningioma. occurs more frequently in intraoral reconstruction ${ }^{12}$ (Fig. 4).

The proportion of temporalis muscle that has to be harvested depends on the localization and size of the defect to be reconstructed. A coronal or sagittal division, or using the muscle complete$l y$, is possible. ${ }^{8}$ When the muscle is to be partially utilized, the anterior portion is used in the reconstruction process and the remaining posterior portion is rotated anteriorly in the temporal fossa. A small muscular strap+ on the anterior temporal crest is preserved which allows the suture of the remaining posterior temporalis muscle after rotation.

\section{Indications}

The anatomical proximity of the temporalis muscle to the upper third and middle third of the face means that it is used relatively frequently in the field of craniofacial reconstruction surgery.

We have used a total of 108 temporalis myofascial flaps with the following indications:

A. Reconstruction of post-maxillectomy defects $(n=44)^{13}$ (Figs. 5-8).

The use of only the anterior portion or all of the temporalis muscle depends on the type of maxillectomy performed (partial or extended). This postresection defect allows transposing the temporalis muscle directly, from its insertion in the temporal fossa under the zygomatic arch until it reaches the oral cavity. The fascia temporal is sutured firmly to the intraoral defect in such a way that the temporalis muscle seals the defect.

Some authors are of the opinion that the zygomatic arch should have a pedicle to the masseter muscle so that the strap of the temporalis muscle is transposed in those patients that have previously received local radiotherapy. Reconstruction of the alveolar bone rim is possible by joining the infraorbital rim and the pterygoid process with grafts from the iliac crest six months after surgery. Later rehabilitation with prostheses will be completed using osseointegrated implants six months later. On occasions carrying out vestibu- 
ocasiones es mandatoria una osteotomía cigomática para pasar el colgajo y alcanzar de forma adecuada el defecto a reconstruir. ${ }^{15}$

La fascia del músculo temporal en contacto con la cavidad oral sufre un proceso de metaplasia (Fig. 13) desde la periferia del colgajo siendo ya apreciable en la tercera semana postoperatoria.

D. Exenteración orbitaria $(n=6)$.

Se realiza una fenestración ósea en la pared lateral orbitaria a nivel de la sutura esfenocigomática fijando el músculo temporal a las partes blandas periorbitarias remanentes (Figs. 14-15). El tallado de un injerto libre dermoepidérmico del muslo tapizará la porción externa del músculo temporal el cual obliterará la cavidad orbitaria.

Las indicaciones descritas hasta el momento pertenecen al campo de la patología oncológica $(\mathrm{n}=98)$. 75 pacientes presentaban tumores malignos recibiendo radioterapia postoperatoria 53 de los mismos.

E. Anquilosis de la articulación temporomandibular $(\mathrm{n}=6)$.

Tras la resección del bloque anquilótico (bilateral en 4 pacientes) mediante incisión preauricular se procedió al tallado de una cincha temporal central que se interpone y sutura al cuello condilar remanente con el fin de crear una neoarticulación temporomandibular.

F. Secuelas faciales postraumáticas $(n=2)$ tras agresión con arma de fuego, empleándose para reconstruir defectos óseos conminutos y de partes blandas asociadas en el tercio medio facial

G. Reanimación facial $(n=2)$ mediante técnica de Rubin.

\section{Resultados}

De los 108 colgajos miofasciales temporales tallados se objetivó necrosis total del mismo en 3 casos y parcial en 4, debido a isquemia secundaria a problemas mecánicos en casos de reconstrucción intraoral al ser pediculado bajo el arco cigomático. Asimismo, en este grupo de pacientes se apreció dehis-

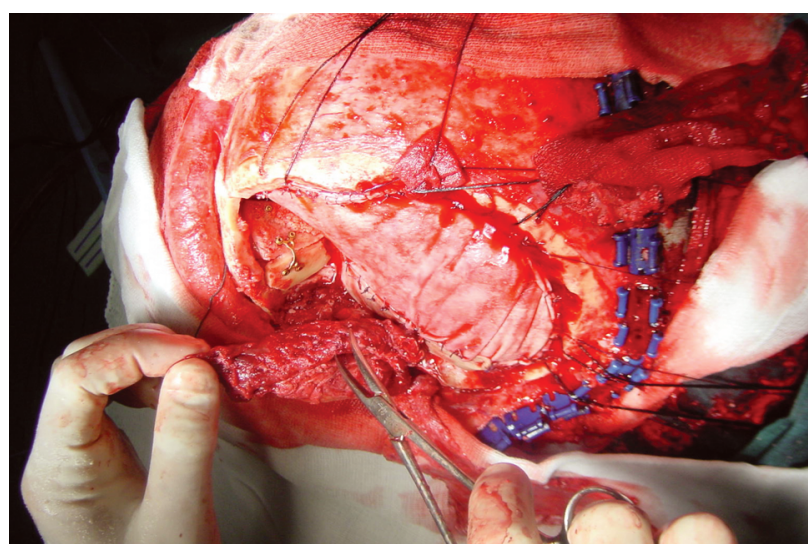

Figura 12. El músculo temporal sella de forma eficaz la fosa craneal anterior y aporta vascularización a los injertos implicados en la reconstrucción orbitaria.

Figure 12. The temporalis muscle seals the anterior cranial fossa efficiently and provides vascularization of the grafts used in orbital reconstruction.

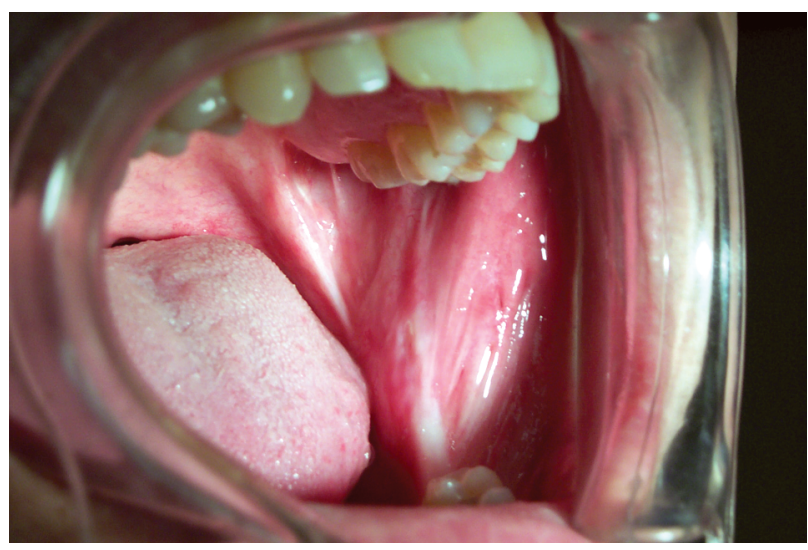

Figura 13. Metaplasia intraoral al tercer mes postoperatorio tras reconstrucción de carcinoma epidermoide de mucosa yugal.

Figure 13. Intraoral metaplasia three months after surgery following reconstruction due to squamous cell carcinoma of the jugal mucosa.

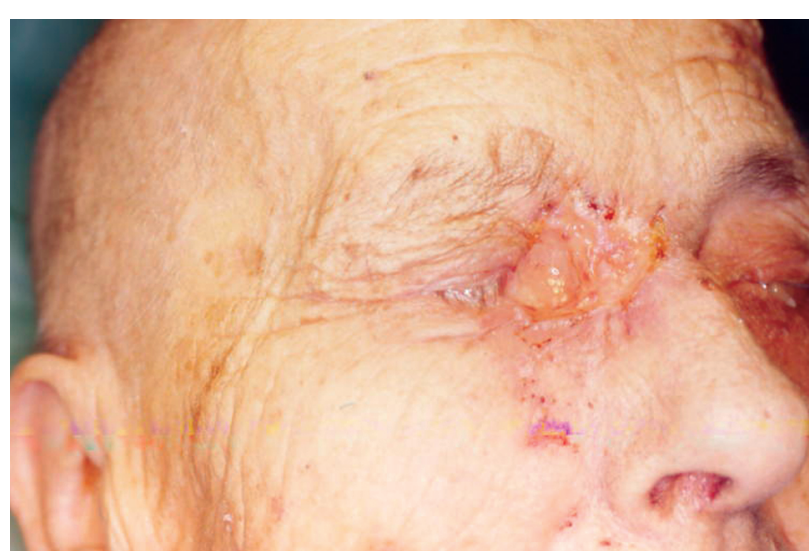

Figura 14. Carcinoma epidermoide palpebral con invasión orbitaria.

Figure 14. Squamous cell carcinoma of the palpebra with orbital invasion. loplasties is necessary in this surgical act.

$B$. Surgery of the skull base $(n=25)$

Postsurgical defects are divided as follows:

B1. Anterior cranial fossa $(n=15)$

- Anterolateral resection $(n=9)$

- Lateral resection ( $n=6)$

B2. Medial cranial fossa $(n=5)$

B3. Posterior cranial fossa $(n=2)$

B4. Clivus $(n=3)$

Adequate isolation is the fundamental objective pursued, in order to avoid dead spaces between the central nervous system and the upper aerodigestive tract $^{14}$ (Fig. 9-10). In this way the appearance of a fistula of cephalorrhachidian liquid and the resulting risk of associated meningitis is avoided.

The temporalis muscle provides a substantial amount of well-vascularized tissue that enables sealing the skull base efficiently, and it can be extended even further than the medial line, to the contralateral side, eliminating in this way any existing dead spaces. In this type of surgical proceedings of the skull base, associated resection is frequent of one or several orbital walls. The temporalis muscle provides a suitable vascular supply for these free bone grafts (Figs. 11 and 12). C. Oral cavity-oropharynx $(n=23)$.

The defects to be reconstructed were divided in the following way:

- Jugal mucosa $(n=8)$

- Soft palate $(n=7)$

- Retromolar trigone $(n=5)$

- Oropharynx ( $n=3)$

The transposition of the temporalis muscle is done 
cencia parcial de la sutura intraoral en 19 casos. 8 pacientes presentaron trismus postoperatorio; en todos ellos el músculo temporal fue empleado para reconstruir defectos oncológicos en trígono retromolar y/o mucosa yugal. Una fisioterapia masticatoria estricta prolongada colabora en la mejoría postquirúrgica de dichos pacientes. En los casos con resección de base de cráneo se evidenció fístula de líquido cefalorraquídeo en 7 pacientes. La aplicación de medidas conservadoras (reposo +/- drenaje lumbar) consiguió la resolución del proceso. Como secuela estética franca se apreció deformidad en la fosa temporal en 13 pacientes, todos ellos pertenecientes a los primeros casos tratados con músculo temporal como método reconstructivo sin tratamiento de relleno adicional de la fosa temporal. Tras el empleo de materiales aloplásticos $(n=20)$ para relleno de la fosa temporal se han detec-
Figura 15. Trasposición de músculo temporal tras fenestración orbitaria.

Figure 15. Transposition of the temporalis muscle following orbital perforation.

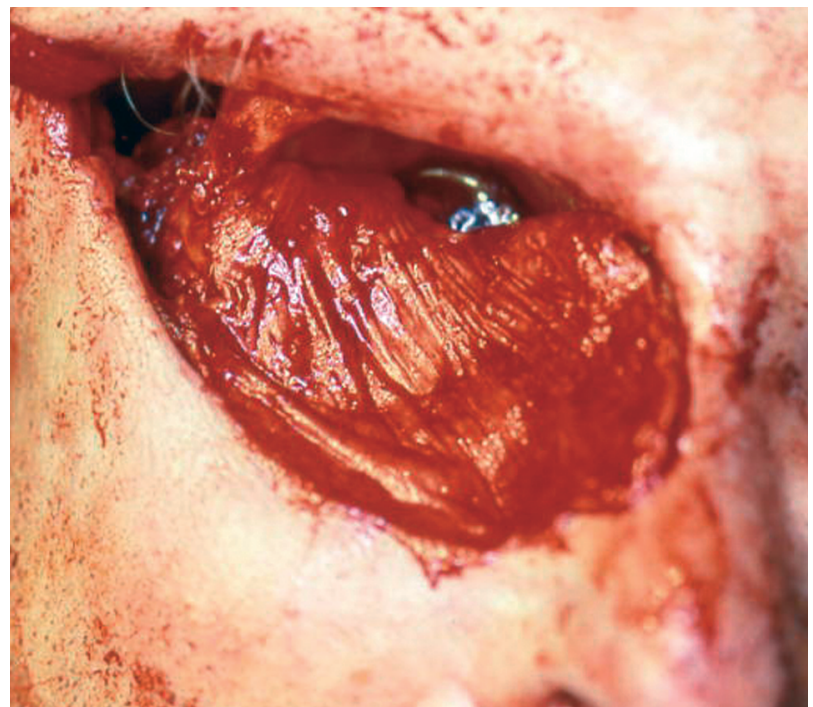

through the tunnel created in the infratemporal fossa under the zygomatic arch. In order to reach the defect that has to be reconstructed properly, a zygomatic osteotomy is sometimes mandatory to pass the flap. ${ }^{15}$

The fascia of the temporalis muscle which is in contact with the oral cavity undergoes a process of metaplasia (Fig. 13) from the peripheral area of the flap, which is noticeable three weeks after surgery.

D. Orbital exenteration $(n=6)$

Bone fenestration is carried out on the orbital wall at the level of the sphenozygomatic suture in order to fix the temporalis muscle to the remaining periorbital soft tistado 5 casos de sobreinfección de dicho material siendo precisa su retirada tras instauración de tratamiento antibiótico. En dos pacientes se apreció parálisis de la rama frontal como consecuencia de la técnica quirúrgica.

\section{Discusión}

A pesar de sus más de 100 años de historia, el colgajo de músculo temporal permanece vigente en el momento actual. Su proximidad anatómica al tercio medio y superior facial lo convierte en una opción segura y versátil como método reconstructivo pediculado locorregional. ${ }^{16}$ Sin embargo, existen otras posibilidades terapéuticas reconstructivas. Algunos autores defienden la colocación de obturadores palatinos obviando así la necesidad de reconstruir el tercio medio facial. Evita interferencias en el posible diagnóstico de recidiva tumoral tras la reconstrucción con músculo temporal. Hoy en día las revisiones periódicas del paciente junto con la evolución alcanzada en las pruebas de imagen facilitan el seguimiento y diagnóstico precoz de nuevos procesos oncológicos asociados y reduce al mínimo el número de pacientes susceptibles de recibir dicha opción terapéutica.

Por otra parte, aporta un volumen cualitativo y cuantitativo de partes blandas bien vascularizadas ${ }^{17}$ adecuado para minimizar la secuela estética asociada a la ausencia reconstructiva en el tercio medio facial.

Otras opciones reconstructivas están constituídas por los colgajos de scalp, los cuales generan una importante deformidad estética y aportan tejido capilar en zonas carentes del mismo y los colgajos musculocutáneos pediculados regionales pectoral o trapecial que aportan excesivo volumen y cuya localización distante al defecto requiere extensas disecciones toracocervicofaciales. ${ }^{11}$ sues (Figs. 14-15). The harvesting of a dermoepidermic free graft from the thigh will cover the external portion of the temporalis muscle and close the orbital cavity.

The indications described so far belong to the area of oncological pathology ( $n=98)$. 75 patients presented malignant tumors and 53 had postoperative radiotherapy.

E. Ankylosis of the temporomandibular joint $(n=6)$

Following resection of the ankylotic block (bilateral in four patients) by means of a preauricular incision, a central temporal strap was then harvested and the remaining condylar neck was sutured so as to create a temporomandibular neo-articulation.

F. Post-traumatic facial sequelae $(n=2)$ following fire arms aggression. Used for comminuted bone defects and soft tissues associated with the middle third of the face.

G. Facial reanimation ( $n=2)$ using Rubin's technique.

\section{Results}

Of the 108 temporalis myofascial flaps harvested, total necrosis occurred in three cases and partial necrosis in four, due to ischemia secondary to mechanical problems in intraoral reconstruction cases because of the pedicle passing under the zygomatic arch. Likewise, in this group of patients partial dehiscence of the intraoral suture was observed in 19 cases. Eight patients presented postoperative trismus; in all of them the temporalis muscle was used to reconstruct the oncological defects in the retromolar trigone and/or the jugal mucosa. A strict and prolonged program of masticatory exercises aids postsurgical improvement in these patients. In the cases that required resection of the base of the skull, a fistula of cephalothoracopagus 
Por último, frente a los colgajos libres microvascularizados, aporta una menor morbilidad en la zona donante, un menor tiempo quirúrgico dada la relativa sencillez de la técnica y evita los cambios posturales del paciente durante el acto quirúrgico. Sin embargo, aporta una menor cantidad y variedad de tejidos útiles para una estricta reconstrucción anatómica estético-funcional.

De esta forma, estaría indicada la utilización de colgajos libres microvascularizados en pacientes con defectos extensos complejos tridimensionalmente y en aquellos en los que el músculo temporal no estuviera disponible.

La mayor desventaja del músculo temporal es la secuela estética residual como consecuencia del hundimiento temporal provocado. ${ }^{13}$ Se han propuesto varias técnicas para minimizar la deformidad creada en la fosa temporal:

- La línea del pelo temporal anterior comienza aproximadamente $4 \mathrm{~cm}$. tras el reborde orbitario lateral. Es en esta región donde la deformidad es más notoria. Tras tallar el colgajo de músculo temporal se preserva una cincha muscular fija a la fosa temporal en su inserción en la cresta temporal anterior. Si no ha sido utilizado todo el músculo temporal, la porción posterior se rota y se sutura a la cincha muscular anterior disminuyendo así la deformidad residual.

- Utilización de materiales aloplásticos para relleno de la fosa temporal en casos de empleo completo del músculo temporal (Figs. 16-17). Su uso

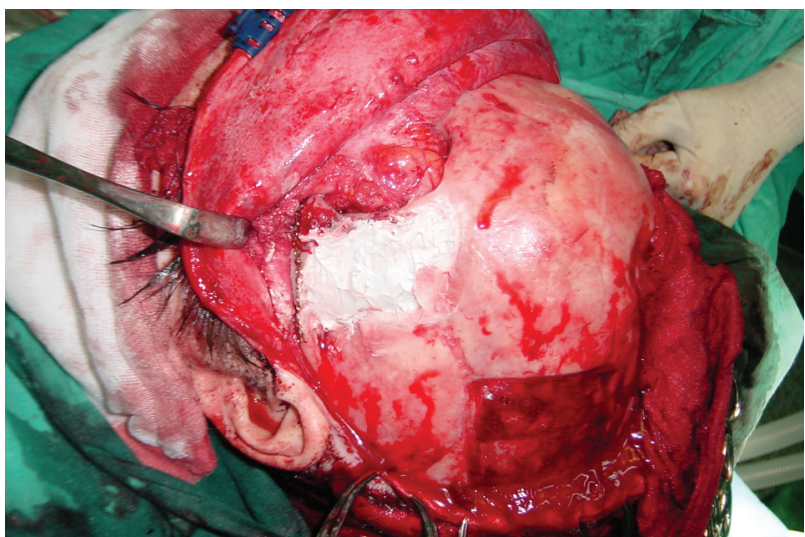

Figura 16. Material aloplástico para relleno de fosa temporal. Figure 16. Alloplastic material for filling the temporalis fossa.

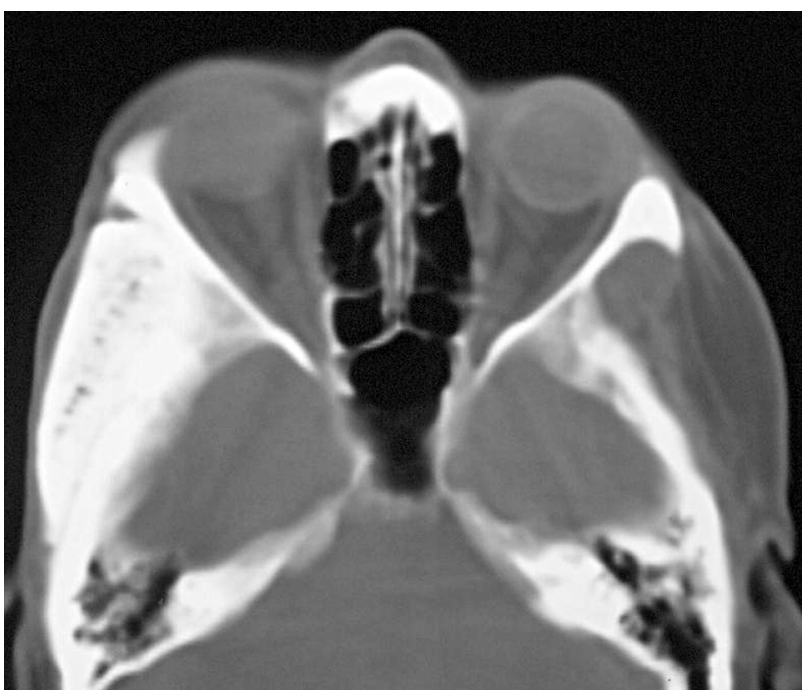

Figura 17. TAC control. Volumen adecuado en fosa temporal tras relleno.

Figure 17. CT control [showing] adequate bulk following filling in of the temporal fossa.

liquid appeared in seven patients. The process was resolved with the application of conservative measures (rest and/or lumbar drainage). Deformity, as in obvious aesthetic sequelae, was observed in the temporal fossa of 13 patients belonging to the first group in which the temporalis muscle was used as a reconstructive method. They had not been given treatment regarding additional filling of the temporal fossa. Following the use of alloplastic material $(n=20)$ for filling the temporal fossa, five cases of hyperinfection were detected with this material and removal was necessary following prescription of antibiotics. In two patients paralysis of the frontal branch was noted as a consequence of the surgical technique.

\section{Discussion}

In spite of having a history of more than 100 years, the temporalis muscle is to date still a valid option. Its anatomical proximity to the middle and superior third of the face, make it a reliable and versatile option as a en pacientes que van a recibir radioterapia postoperatoria aumenta la posibilidad de infección de dichos materiales por movilidad asociada.

- Tallado de fascia parietotemporal para relleno del defecto creado y/o colgajos de galea-pericraneo frontoparietal.

- Disección de la bolsa de grasa temporal y trasposición a la fosa temporal. ${ }^{18}$

\section{Conclusiones}

1. El colgajo de músculo temporal sigue siendo hoy día una opción versátil y segura en cirugía reconstructiva del tercio superior y medio facial.

2. Aporta tejido muscular bien vascularizado útil en la cobertura de injertos óseos empleados en reconstrucción del tercio medio other therapeutic reconstructive possibilities exist. Some authors defend the use of obturators of the palate avoiding in this way having to reconstruct the middle third of the face. This avoids complications if there is a diagnosis of tumor relapse following reconstruction with the temporalis muscle. Currently, periodic check-ups of the patient, together with the advances in imaging tests, allow for the tracking and early diagnosis of any new and related oncological processes, and the number of patients susceptible to receiving this therapeutic option is reduced to a minimum.

On the other hand [the temporalis muscle] provides bulk, having both quality and quantity together with well-vascularized soft tissue, 17 and it is suitable for minimizing the aesthetic sequelae associated with the lack of reconstruction in the middle third of the face. locoregional, pedicled reconstruction method. ${ }^{16}$ However, 
facial susceptibles de tratamiento con radioterapia coadyuvante.

3. La disección traumática del colgajo y su sutura a tensión predisponen la aparición de complicaciones como necrosis o dehiscencia de sutura.

4. Asegura en cirugía de base de cráneo un aislamiento eficaz del sistema nervioso central, obliterando espacios muertos y evitando la aparición de fístula de líquido cefalorraquídeo postquirúrgica.

\section{Bibliografía}

1. Lentz J. Ankylose osseuse de la mâchoire inférieure, résection du col condyle avec interposition du muscle temporal entre les surfaces de résection. Congrés Franc de Chir 1895;113.

2. Golovine SS. Procede de clôture plastique de I'orbite après I'exenteration. Arch Ophtalmol 1898;18:679.

3. Gillies HD, H. Frwde (ed). Plastic Surgery of the Face. London: Oxford University Press 1920;40:54-55.

4. Campbell HH. Reconstruction of the left maxilla. Plast Reconstr Surg 1948;3:66.

5. Antonyshyn O, Gruss JS, Birt BD. Versatility of temporal muscle and fascial flaps. Br J Plast Surg 1988;41:118.

6. Shagets FW, Panje WR, Shore JW. Use of temporalis muscle flaps in complicated defects of the head and face. Arch Otolaryngol Head Neck Surg 1986;112:60.

7. Mathes SJ, Nahai F. Classification of the vascular anatomy of muscles: experimental and clinical correlation. Plast Reconstr Surg 1981;67:177-87.

8. Cheung LK. The vascular anatomy of the human temporalis muscle: implications for surgical splitting techniques. Int J Oral Maxillofac Surg 1996;25:414-421.

9. Chen Ch-T, Robinson JB, Rohrich RJ, Ansari M. The blood supply of the reverse temporalis muscle flap: anatomic study and clinical implications. Plast Reconstr Surg 1999;103:1181-1188.

10. Cheney ML, Varvares MA, Nadol JB. The temporoparietal facial flap in head and neck reconstruction. Arch Otolaryngol Head Neck Surg 1993;119:618-623.

11. Shagets MFW, Panje WR, Shore LCJW. Use of temporalis muscle flaps in complicated defects of the head and face. Arch Otolaryngol Head Neck Surg 1986; 112:60-65.

12. Colmenero C, Martorell V, Colmenero B, Sierra I. Temporalis myofascial flap for maxillofacial reconstruction. J Oral Maxillofac Surg 1991;49:1063-1067.

13. Cordeiro PG, Wolfe SA. The temporalis muscle flap revisited on its centennial: advantages, newer uses and disadvantages. Plast Reconstr Surg 1996;98:980-987.

14. Yucel A, Yazar S, Aydin Y, Seradjimir M, Altintas M. Temporalis muscle flap for craniofacial reconstruction after tumor resection. J Craniofac Surg 2000;11(3): 258-264.

15. Abubaker AO, Abouzgia MB. The temporalis muscle flap in reconstruction of intraoral defects: an appraisal of the technique. Oral Surg Oral Med Oral Pathol Oral Radiol Endod 2002;94(1):24-30.

16. Hanasono MM, Utley Ds. Goode RL. The temporalis muscle flap for reconstruction after head and neck oncologic surgery. Laryngoscope 2001;111(10): 1719-1725.

17. Alonso del Hoyo J, Fernandez Sanroman J, Gil Diez JL, Diaz Gonzalez FJ. The temporalis muscle flap: an evaluation and review of 38 cases. J Oral Maxillofac Surg 1994;52(2):143-147.

18. Stuzin JM, Wagstrom L, Kawamoto HK, Wolfe SA. Anatomy of the frontal branch of the facial nerve: The significance of the temporal fat pad. Plast Reconstr Surg 1989;83:265.
Other reconstructive options consist in scalp flaps, which generate considerable aesthetic deformity and supply capillary tissue in areas that lack it, and regional pedicled musculocutaneous flaps, either trapezius or pectoral, which provide too much bulk and which require extensive thoracocervicofacial dissection due being located at a distance from the defect.11

Lastly, compared with microvascularized free flaps, there is lower donor site morbidity, less surgical time is required given the relatively simple technique, and postural changes are avoided in the patient during the surgical act. However, for a strict anatomical, aesthetic/functional reconstruction the quantity and variety of tissues that can be used is inferior.

In this way, the use of microvascularized free flaps would be indicated in patients with extensive and complex tri-dimensional defects, and in those in which the temporalis muscle was not available.

The greatest disadvantage of the temporalis muscle is the resulting aesthetic sequelae due to the hollow that appears in the temple. ${ }^{13}$ Various techniques have been proposed in order to minimize the deformity created in the fossa temporal:

- $\quad$ The anterior temporal hairline starts approximately 4 $\mathrm{cm}$. behind the lateral orbital rim. It is in this area that deformity is most commonly found. After the harvesting of the temporalis muscle, a muscular strap is preserved and fixed to the temporal fossa at the point of insertion into the anterior temporal crest is preserved. If all of the temporalis muscle has not been used, it is rotated and sutured to the anterior muscular strap and the residual deformity is in this way reduced.

- Using alloplastic material for filling the temporal fossa in cases where the temporalis muscle has been used completely (Figs. 16-17). Its use in patients that are going to receive postoperative radiotherapy increases the possibility of infection in these materials due to related mobility.

- Parietotemporal fascia harvesting for filling in the defect created and/or frontoparietal galea-pericranial flaps.

- Dissection of the temporal fat sac and its transposition to the temporal fossa. ${ }^{18}$

\section{Conclusions}

1. The temporalis muscle flap is still today a safe and versatile option in reconstructive surgery of the upper and middle third of the face.

2. It provides well-vascularized muscular material which is useful for covering bone grafts used in the reconstruction of the middle third of the face and which are susceptible to treatment with additional radiotherapy.

3. Complications such as necrosis or dehiscence of the suture are more likely to arise following traumatic dissection of the flap and tension to the suture.

4. It ensures efficient isolation of the central nervous system in skull base surgery, eliminating dead spaces and avoiding the appearance of postsurgical fistula of cephalorrahachidian liquid. 